Reading Faulknerian Tragedy 
Also by Warwick Wadlington:

The Confidence Game in American Literature 


\section{Reading Faulknerian Tragedy}

WAR WICK WADLINGTON

CORNELL UNIVERSITY PRESS

ITHACA AND LONDON 
CORNELL UNIVERSITY PRESS GRATEFULLY ACKNOWLEDGES

A GRANT FROM THE ANDREW W. MELLON FOUNDATION THAT AIDED IN BRINGING THIS BOOK TO PUBLICATION.

\section{Copyright (C) 1987 by Cornell University}

All rights reserved. Except for brief quotations in a review, this book, or parts thereof, must not be reproduced in any form without permission in writing from the publisher. For information, address Cornell University Press, I24 Roberts Place, Ithaca, New York I 4850

First published 1987 by Cornell University Press.

International Standard Book Number 0-80I 4-20 I I-3

Library of Congress Catalog Card Number 86-29I66

Printed in the United States of America

Librarians: Library of Congress cataloging information appears on the last page of the book.

The paper in this book is acid-free and meets the guidelines for permanence and durability of the Committee on Production Guidelines for Book Longevity of the Council on Library Resources. 